\title{
Early Suppression Fast Response (ESFR) Sprinkler Protection for 12m High Warehouses
}

\author{
HSIANG-CHENG KUNG, BENNIE G. VINCENT, \\ TAK-SANG CHAN, HONG-ZENG YU and PARASKEVAS STAVRIANIDIS \\ Factory Mutual Research Corporation \\ Norwood, MA 02062 USA
}

\begin{abstract}
A series of seven large-scale rack storage fire tests was conducted, using four ESFR sprinkler models, to determine the required sprinkler spray characteristics for achieving effective protection of rack storages of the FM standard plastic commodity up to $10.8 \mathrm{~m}$ high in a 12.2 $\mathrm{m}$ high warehouse. All four models have a nominal $\mathrm{K}$ factor of $0.34 \mathrm{l} / \mathrm{s} /(\mathrm{kPa})^{1 / 2}$, and the sprinkler discharge pressure was maintained at $517 \mathrm{kPa}$. The sprinkler spacing was $3.05 \mathrm{~m} \mathrm{x}$ $3.05 \mathrm{~m}$. The test variables include storage height/ceiling clearance, ignition location and sprinkler models. The sprays of the sprinkler models used in the fire tests were characterized by their drop size distribution, center-core thrust force, and water distribution under no-fire condition. For ESFR sprinkler protection, the effect of drop size distribution was demonstrated to be unimportant through the fire tests. For the case with ignition directly over a sprinkler, the spray center-core thrust force and the water flux under no-fire condition over the top surface of a two pallet-load by two pallet-load fuel array directly underneath the sprinkler have been shown to be critical for achieving fire suppression. A minimum centercore thrust force of $101.3 \mathrm{~N} / \mathrm{m}^{2}$ measured at 1.77 beneath the sprinkler deflector, and a minimum water flux of $0.614 \mathrm{l} / \mathrm{s} / \mathrm{m}^{2}$ measured over a $2.15 \mathrm{~m} \times 2.15 \mathrm{~m}$ area $4.42 \mathrm{~m}$ beneath the ceiling directly under the sprinkler have been found to be necessary for achieving fire suppression. For the case with ignition centered below two sprinklers and with $10.8 \mathrm{~m}$ storage height / $1.77 \mathrm{~m}$ ceiling clearance, only the water flux under no-fire condition over the fuel array top was shown to be critical. A measured water flux of $0.667 \mathrm{l} / \mathrm{s} / \mathrm{m}^{2}$ over a $2.15 \mathrm{~m}$ $\mathrm{x} 2.15 \mathrm{~m}$ area, centered below the two sprinklers, 1.77 beneath the ceiling, was found to be sufficient for achieving fire suppression.
\end{abstract}

KEYWORDS: ESFR sprinkler, rack storage fire, center core thrust force, water distribution 


\section{INTRODUCTION}

From 1984 to 1988, Factory Mutual Research Corporation (FMRC) conducted a sprinkler research program with the objective of providing effective protection for warehouse occupancies, which culminated in the development of Early Suppression Fast Response (ESFR) sprinklers ${ }^{(1)}$. ESFR sprinklers are equipped with a fast-response actuation mechanism to respond to a fire in its early stage of fire development, and are designed to deliver sufficient amounts of water to the burning fuel so that the fire can be suppressed shortly after sprinkler operation. Consequently, fire, smoke and water damage may be greatly reduced. ESFR sprinkler protection was originally intended for storage of ordinary combustibles (Class I through Class IV Commodities, and Cartoned Plastic Commodities ${ }^{(2)}$ ), up to $7.6 \mathrm{~m}$ high in warehouses up to $9.1 \mathrm{~m}$ high. The water demand requirement of an ESFR sprinkler system is to provide water discharge from 12 operating sprinklers at $345 \mathrm{kPa}^{(3)}$.

In the ESFR Research Program, the Required Delivered Densities (RDD) for fire suppression of 3.05, 4.57, 6.10 and $7.6 \mathrm{~m}$ high rack storages of the Standard Plastic Commodity ${ }^{(4)}$ were determined $^{(4,5)}$. Furthermore, we measured the Actual Delivered Density (ADD) ${ }^{(1)}$ of prototype sprinklers at $345 \mathrm{kPa}$. The ADD/RDD relationship was used to aid the development of ESFR sprinklers. However, the effectiveness of ESFR sprinklers for protection of $9.1 \mathrm{~m}$ high warehouses was evaluated through a series of large-scale fire tests $^{(6,7,8)}$.

Shortly after the introduction of ESFR sprinklers to the fire protection community, there was a great demand to use ESFR sprinklers in $12.2 \mathrm{~m}$ high warehouses with rack storages up to $10.8 \mathrm{~m}$ high. Since there have been no RDD data for rack storage with heights greater than $7.6 \mathrm{~m}$, it was not possible to use the ADD/RDD relationship to gain insight into the ESFR sprinkler effectiveness for protection of $12.2 \mathrm{~m}$ high warehouses with storages up to $10.8 \mathrm{~m}$ high. Therefore, large-scale testing was used to evaluate ESFR sprinkler effectiveness for protection of $12.2 \mathrm{~m}$ high warehouses. This paper presents results of a series of seven largescale rack storage fire tests with a $12.2 \mathrm{~m}$ ceiling height. The test variables include storage height/ceiling clearance, ignition location and ESFR sprinkler models. The sprays of the sprinkler models used in the fire tests were characterized in terms of volumetric median drop diameter, center-core thrust force and sprinkler water distribution. The fire test results were correlated with the spray characteristics in order to determine the required spray characteristics for achieving effective fire protection of $12.2 \mathrm{~m}$ high warehouses. These requirements have been adopted in the FMRC approval Standard for ESFR sprinklers.

\section{FIRE TESTS}

All fire tests were conducted at the FMRC Test Center in West Glocester, RI. Overall dimensions of the test building are $61 \mathrm{~m} \mathrm{x} 76 \mathrm{~m}$ with two floor-to-ceiling heights, $9.1 \mathrm{~m}$ and $18.3 \mathrm{~m}$. The tests were conducted at the $18.3 \mathrm{~m}$ ceiling-height site. A $6.1 \mathrm{~m}$ high platform was constructed to hold the fuel arrays and provide a $12.2 \mathrm{~m}$ floor-to-ceiling height. During each test, no forced ventilation was provided, and all doors and windows of the test volume communicating to the outside were closed. 
Fuel for fire tests consisted of pallet loads of the Factory Mutual Standard Plastic Commodity. The commodity consisted of polystyrene cups packaged in compartmented, single-wall corrugated paper cartons; each measured $0.533 \mathrm{~m}$ by $0.533 \mathrm{~m}$ by $0.508 \mathrm{~m}$ high, and contained 125 compartments (five levels of compartments with 25 compartments on each level). Eight cartons of the Standard Plastic Commodity were placed on a wood pallet forming a stack two cartons wide by two cartons deep by two cartons high. The weight of the polystyrene cups per pallet load was $29.3 \mathrm{~kg}$; the weight of empty cartons with compartment dividers per pallet load was $21.8 \mathrm{~kg}$, while the weight of wooden pallets ranged from $23.1 \mathrm{~kg}$ to $24.1 \mathrm{~kg}$. Double-row steel racks were used to hold pallets of the commodity. The main fuel array was either two-pallet-loads wide by two-pallet-loads deep, or two-pallet-loads wide by four-palletloads deep. The arrangement of a $2 \times 2 \times 4$ (four tier high) fuel array is shown in Figure 1 of Reference 6.

Ignition for the fuel array consisted of four cotton-cloth rolls $(7.6 \mathrm{~cm}$ diameter, $7.6 \mathrm{~cm}$ long), each soaked with $118 \mathrm{ml}$ of gasoline and wrapped in a plastic bag. The four ignition rolls were placed near the bottom of the center flue space of the fuel array, as shown in Figure 16 of Reference 4. A propane torch was used to ignite the rolls.

To provide ESFR sprinkler protection of rack storages up to $7.6 \mathrm{~m}$ high in a $9.1 \mathrm{~m}$ high warehouse, a water discharge pressure of $345 \mathrm{kPa}$ is required, which gives a discharge rate of $6.34 \mathrm{l} / \mathrm{s}$ per sprinkler. It is expected that a higher discharge pressure would be required in order to achieve fire suppression of rack storages up to $10.7 \mathrm{~m}$ high in a $12.2 \mathrm{~m}$ high warehouse. Therefore, a sprinkler discharge pressure of $517 \mathrm{kPa}$ (at a discharge rate of 7.65 $\ell / s$ per sprinkler) was selected for the test program. The sprinkler spacing was maintained at $3.05 \mathrm{~m} \times 3.05 \mathrm{~m}$.

Other test variables of the seven rack storage fire tests are presented in Table 1. The first six tests were conducted to investigate the effectiveness of ESFR sprinklers in suppressing a rack storage fire directly under a sprinkler spray. It has been shown that for a $9.14 \mathrm{~m}$ high ceiling with Large-Drop sprinklers, the fire of $6.10 \mathrm{~m}$ high rack storage with a $3.05 \mathrm{~m}$ ceiling clearance (distance between the ceiling and the top surface of the storage) presented a greater challenge to the sprinklers than the fire of a $7.62 \mathrm{~m}$ high rack storage with $1.52 \mathrm{~m}$ ceiling clearance when the fire was directly underneath a sprinkler ${ }^{(9)}$. The larger ceiling clearance permits the fire plume to develop stronger before sprinkler actuation. The upward flow of a strong plume tends to blow the sprinkler water drops away from the fire and reduce the water flux delivered to the fire ${ }^{(10)}$. However, if the fire plume is overpowered by the sprinkler spray, effective delivery of sprinkler water to the fire source is expected. The ability of a sprinkler spray to overpower a fire plume depends on the momentum flux of the fire plume and the thrust force of the spray. The plume momentum flux is a function of the convective heat flux of the fire and the plume width, which in turn depend on the storage height and ceiling clearance. For a given discharge pressure, the thrust force of a sprinkler spray is determined by the sprinkler design. In the first six tests, two large ceiling clearances: $5.94 \mathrm{~m}$ clearance with a $6.25 \mathrm{~m}$ high rack storage, and $4.42 \mathrm{~m}$ clearance with a $7.77 \mathrm{~m}$ high storage, were employed. For the $6.25 \mathrm{~m}$ high rack storage, two sprinkler models: ESFR-1 and CPK, were evaluated (Tests 1 and 2), while for the $7.77 \mathrm{~m}$ high rack storage, four sprinkler models: ESFR-1, CPK, P1 and P3, were evaluated (Tests 3 through 6). All four sprinklers have a nominal $\mathrm{K}$ factor of $0.34 \mathrm{l} / \mathrm{s} /(\mathrm{kPa})^{1 / 2}\left(14 \mathrm{gpm} /(\mathrm{psi})^{1 / 2}\right)$, and a temperature rating of $73^{\circ} \mathrm{C}$ with a 
TABLE 1. FIRE TEST RESULTS AND SPRINKLER DISCHARGE CHARACTERISTICS

\begin{tabular}{|c|c|c|c|c|c|c|c|c|c|}
\hline & $\begin{array}{l}\text { Fire } \\
\text { Test } \\
\text { No. } \\
\end{array}$ & $\begin{array}{c}\text { Ignition } \\
\text { Centered } \\
\text { Below } \\
\text { No. of Spr. }\end{array}$ & $\begin{array}{c}\text { Storage } \\
\text { Height } \\
(\mathrm{m}) \\
\end{array}$ & $\begin{array}{c}\text { Ceiling } \\
\text { Clearance } \\
(\mathrm{m})\end{array}$ & $\begin{array}{l}\text { Sprinkler } \\
\text { Model }\end{array}$ & $\begin{array}{c}\text { Fire } \\
\text { Suppression }\end{array}$ & $\begin{array}{c}\text { No. of } \\
\text { Sprinklers } \\
\text { Operated } \\
\end{array}$ & $\begin{array}{l}\text { Center }^{1} \\
\text { Core Thrust } \\
\text { Force } \\
\left(\mathrm{N} / \mathrm{m}^{2}\right) \\
\end{array}$ & $\begin{array}{l}\text { Water }{ }^{2} \text { Flux } \\
\text { Over Simulated } \\
\text { Array Top } \\
\left(\ell / \mathrm{s} / \mathrm{m}^{2}\right) \\
\end{array}$ \\
\hline & 1 & 1 & 6.25 & 5.94 & ESFR-1 & Yes & 1 & 145.7 & -- \\
\hline \multirow{6}{*}{ 吕 } & 2 & 1 & 6.25 & 5.94 & CPK & Yes & 1 & 61.1 & -- \\
\hline & 3 & 1 & 7.77 & 4.42 & ESFR-1 & Yes & 1 & 145.7 & 0.701 \\
\hline & 4 & 1 & 7.77 & 4.42 & CPK & No & $>12$ & 61.1 & 0.589 \\
\hline & 5 & 1 & 7.77 & 4.42 & $\mathrm{P} 1$ & Yes & 1 & 101.3 & 0.614 \\
\hline & 6 & 1 & 7.77 & 4.42 & P3 & Yes & 1 & 163.8 & 0.689 \\
\hline & 7 & 2 & 10.82 & 1.37 & ESFR-1 & Yes & 2 & -- & 0.667 \\
\hline
\end{tabular}

Notes: 1. measured over a $0.343 \mathrm{~m}$ diameter circular plate, $1.77 \mathrm{~m}$ beneath the deflector

2. measured over a $2.15 \mathrm{~m} \mathrm{x} 2.15 \mathrm{~m}$ area 
RTI value of $27\left(\mathrm{~m} \mathrm{~s}^{1 / 2}\right.$. The fuel array was two pallet-loads wide by two pallet-loads deep by four or five pallet-loads high, and was centered below an array of $7 \times 7$ ESFR sprinklers as shown in Figure 1a.

Test 7 is to evaluate the overlapping ability of ESFR sprinkler sprays in delivering a sufficient amount of water to suppress a fire centered below two sprinklers. Small ceiling clearance presents a challenge condition for the sprinkler overlapping ability. In Test 7, a ceiling clearance of $1.37 \mathrm{~m}$ with a storage height of $10.82 \mathrm{~m}$ was employed. The fuel arrangement consisted of a main fuel array and two target arrays, as shown in Figure 1b. The main array was two pallet-loads wide by four pallet-loads deep by seven pallet-loads high. The target arrays were separated from the main array by a $1.22 \mathrm{~m}$ aisle, and were one pallet-load wide by two pallet-loads deep by seven pallet-loads high. The main fuel array was centered below two sprinklers installed on adjacent branchlines. A total of 49 sprinklers were installed at the ceiling. All the sprinklers were installed with deflectors $0.36 \mathrm{~m}$ below the ceiling.

In the test program, a fire was considered to be successfully suppressed if the following conditions were met: 1) the major fire damage was limited to the center flues of the main array and damage outside the center flues involved only one tier of commodities; 2) only one sprinkler actuated for the case with ignition directly underneath a sprinkler; and 3) no more than six sprinklers actuated for the case with ignition centered below two sprinklers. The fire suppression results of the seven tests are presented in Table 1.

In Tests 1 and 2 with $6.25 \mathrm{~m}$ storage height / $5.94 \mathrm{~m}$ ceiling clearance, both sprinkler models ESFR-1 and CPK suppressed the fire. However, with $7.77 \mathrm{~m}$ storage height / $4.42 \mathrm{~m}$ ceiling clearance, Sprinkler ESFR-1 suppressed the fire in Test 3, but Sprinkler CPK did not suppress the fire, although both Sprinklers ESFR-1 and CPK are approved ESFR sprinklers for protection of $9.1 \mathrm{~m}$ high warehouses. The other two sprinkler models, P1 and P3, were modified from Sprinkler CPK by cutting 12 tines of the deflector instead of 10 tines. Furthermore, sprinkler P3 has a different water jet splitter than sprinklers CPK and P1 (see Figure 2). In Tests 5 and 6 with $7.77 \mathrm{~m}$ storage height $/ 4.42 \mathrm{~m}$ ceiling clearance, both Sprinklers P1 and P3 suppressed the fire. In Test 7 with $10.82 \mathrm{~m}$ storage height $/ 1.37 \mathrm{~m}$ clearance, sprinkler model ESFR-1 was used and ignition was centered below two sprinklers; two sprinklers operated and suppressed the fire.

\section{DROP SIZE, THRUST FORCE AND WATER DISTRIBUTION}

For a given fire located directly underneath a sprinkler spray, the amount of water delivered to the top surface of the fuel array is expected to be affected by the drop size distribution, the center core thrust force and water distribution under no fire condition. In Test 3, Sprinkler ESFR-1 suppressed the fire, while in Test 4, Sprinkler CPK did not, although both sprinklers had the same orifice diameter and discharged at the same pressure. Therefore, we first investigate the effect of drop size distribution of the two sprinklers on their fire suppression performance. Drop size distributions were measured for Sprinklers ESFR-1 and CPK at 345 $\mathrm{kPa}$ discharge pressure, using the FMRC PMS Drop-Size Measuring System ${ }^{(11)}$. The system and measurement procedure are described in References 11 and 12, respectively. Comparison of gross drop size distributions for sprinklers ESFR-1 and CPK at $345 \mathrm{kPa}$ is shown in Figure 


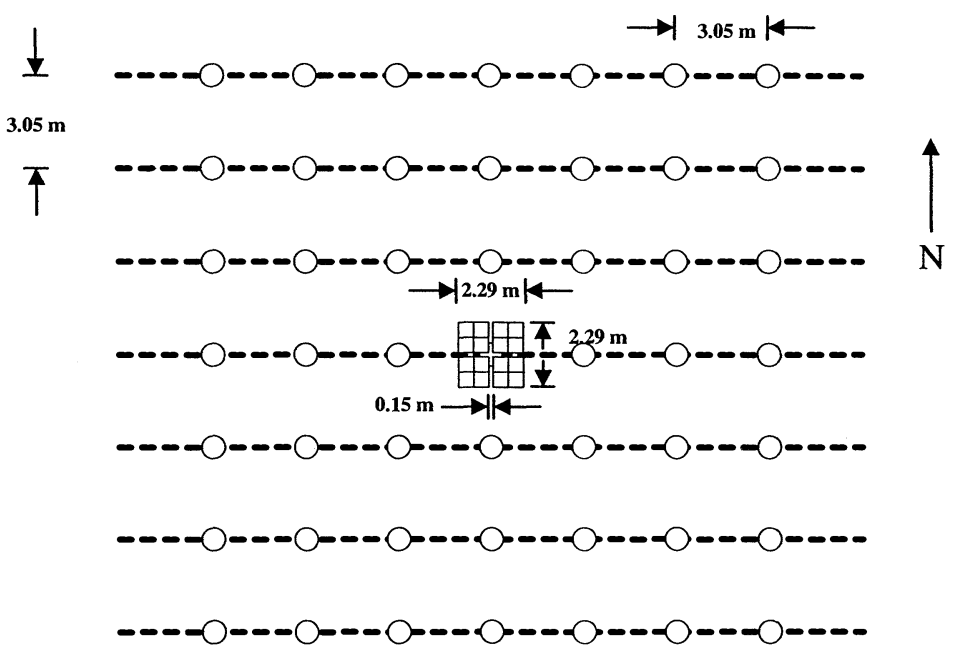

(a) Fuel Array Directly Under A Sprinkler
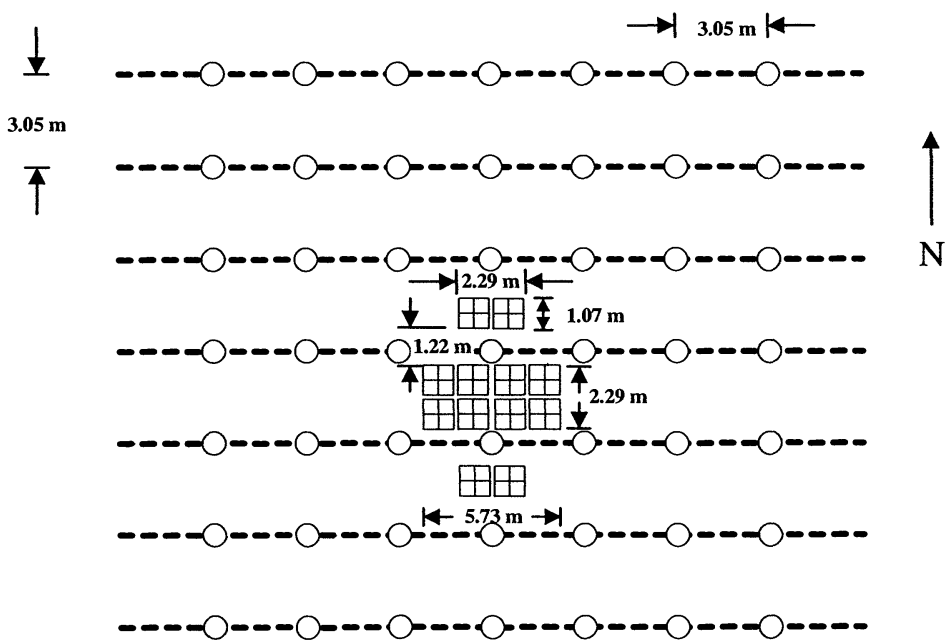

(a) Main Fuel Array Centered Below Two Sprinklers

Figure 1. Fuel Array Location With Respect to Sprinkler Layout 


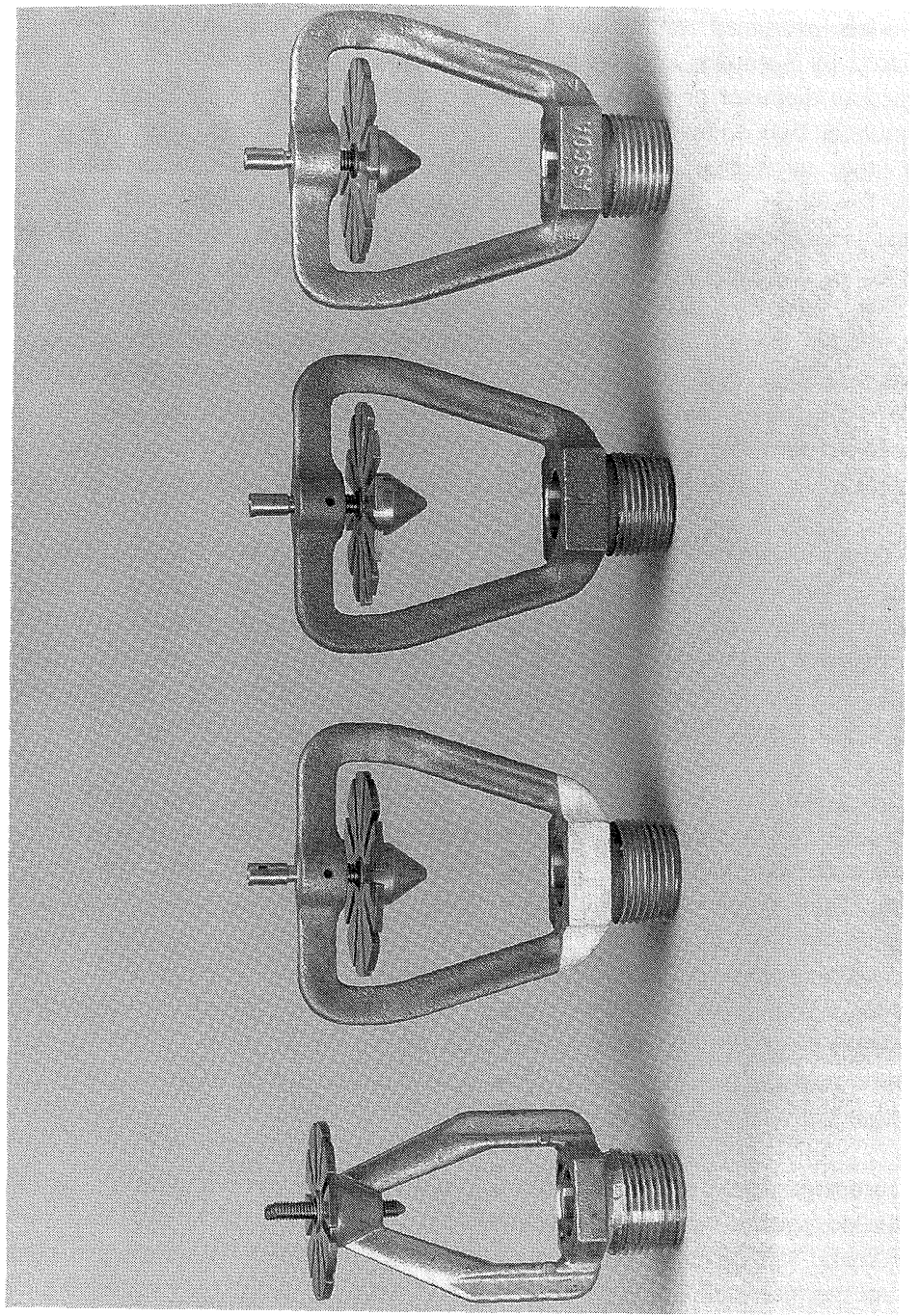

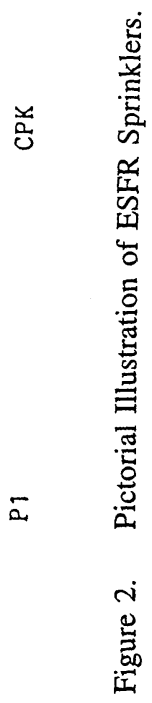

交 
3. The two models produced similar drop size distributions; however, the drop size distribution produced by Sprinkler ESFR-1 is uniformly smaller than that of Sprinkler CPK. The volumetric median diameter of a spray is defined as the diameter which divides the total volume of the spray in two equal parts; one part contains drops smaller than the median diameter, and the other part contains drops greater than the median diameter. The volumetric median diameters for Sprinklers ESFR-1 and CPK at $345 \mathrm{kPa}$ are 0.67 and $0.72 \mathrm{~mm}$, respectively. It has been shown ${ }^{(13,14)}$ that the volumetric median diameter of a sprinkler spray varies as $-1 / 3$ power of the discharge pressure. Therefore, the volumetric median diameters for Sprinklers ESFR-1 and CPK at the discharge pressure of $517 \mathrm{kPa}$ employed in the fire tests can be derived from this relationship and are 0.59 and $063 \mathrm{~mm}$, respectively. In Test 3, the spray of Sprinkler ESFR-1 with smaller median diameter suppressed the $7.77 \mathrm{~m}$ high rack storage fire, while in Test 4 the spray of Sprinkler CPK with larger median diameter did not. Therefore, for an ESFR sprinkler discharging at $517 \mathrm{kPa}$ directly over the fire in Tests 3 and 4, drop size was not considered to be a critical factor for achieving fire suppression.

If the center core thrust force of the spray is sufficiently large to overpower the fire plume, the sprinkler water flux over the top surface of the fuel array under no fire condition is expected to be close to that under the fire condition ${ }^{(10)}$. The center core thrust force and the sprinkler water flux (water distribution) under no fire condition were measured for Sprinklers ESFR-1, $\mathrm{CPK}, \mathrm{P} 1$ and $\mathrm{P} 3$ at $517 \mathrm{kPa}$ discharge pressure in order to correlate these spray characteristics with their fire suppression performance.

For the center-core thrust force measurement, an open ESFR sprinkler was installed on a nominal 2 in. diameter pipe. Water was supplied from one end of the pipe, and a water pressure tap was installed at the other end of the pipe. The water flow to the pipe could be turned on or off rapidly by a pneumatic ball valve. The two deflector-supporting arms of the sprinkler were aligned with the pipe. The thrust force was measured with a $0.343 \mathrm{~m}$ diameter circular plate centered under one sprinkler, $2.13 \mathrm{~m}$ beneath the ceiling. The center-core thrust force of the spray impinging on the plate was monitored by a load cell transducer (GSE Model $4850,4.5 \mathrm{~kg}$ capacity) protected in a waterproof enclosure under the plate. The force signal from the load cell transducer was processed with a strain gage signal conditioner (Analog Devices 3816) before being recorded by a DEC MINC 11/23 data acquisition system.

Before each measurement, water was discharged through the open sprinkler and the pressure was adjusted to the designated values. The water flow to the sprinkler was then shut off by activating the pneumatic ball valve. After the sprinkler stopped dripping, the combined weight of the water film on the plate and the plate itself was recorded for 25 seconds as the baseline weight. The water flow to the sprinkler was resumed immediately after the recording, and the thrust force was recorded for a period of five minutes at one data scan per second.

The water distribution was measured in a $2.15 \mathrm{~m} \mathrm{x} 2.15 \mathrm{~m}$ area, $4.42 \mathrm{~m}$ beneath the ceiling, directly under an ESFR sprinkler. The area simulated the top of a rack-storage fuel array two-pallet-loads wide and two-pallet loads deep separated by $0.15 \mathrm{~m}$ flues. Water distribution to the flue space was measured using four pans; distribution to top surfaces of the commodities was measured with 16 pans. Each pan had a hole at the bottom through which water was channeled to a $40 \ell$ graduated container via a PVC hose. 


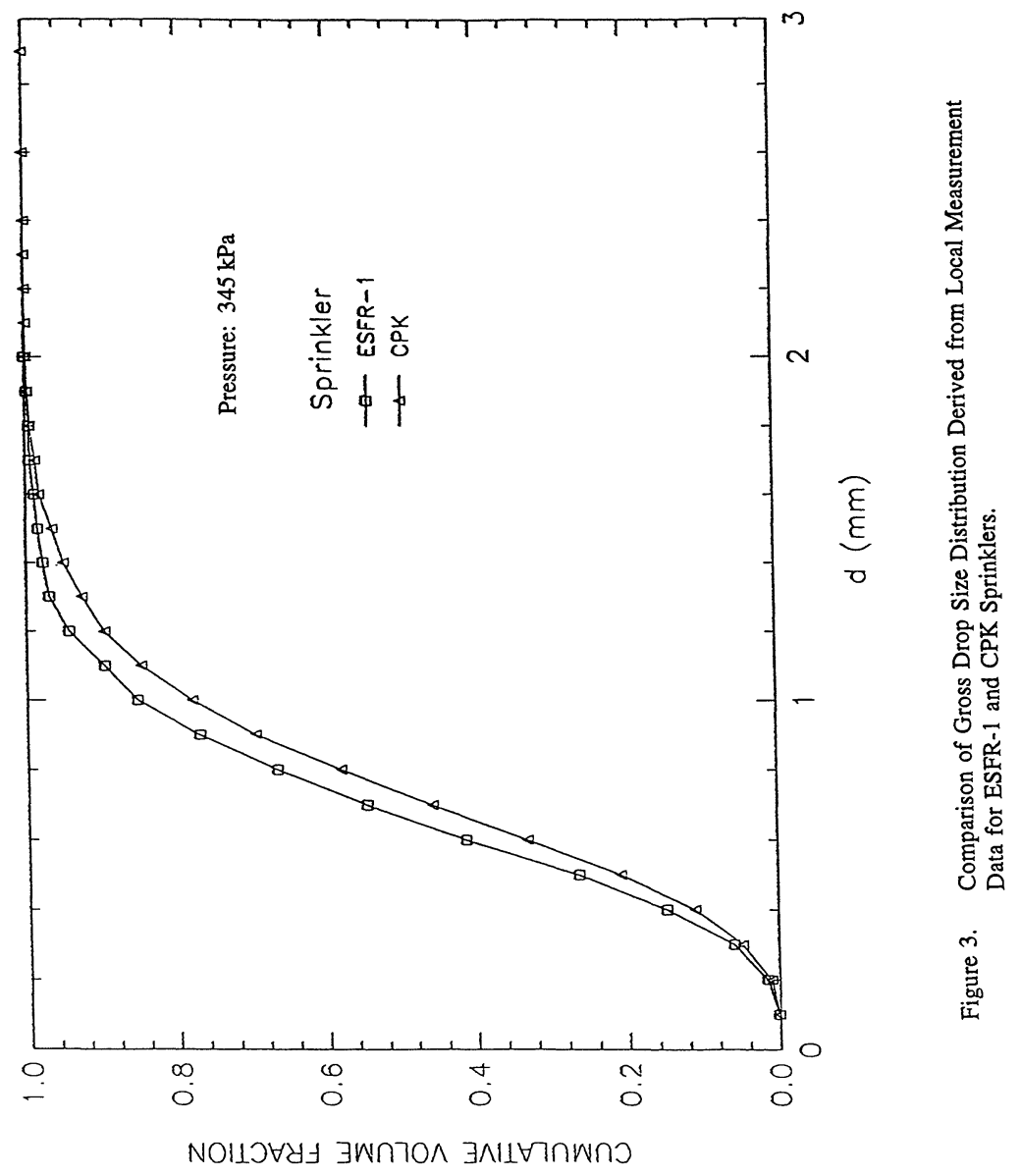


The measured center-core thrust forces per square meter are 61.1, 145.7, 101.3 and 163.8 $\mathrm{N} / \mathrm{m}^{2}$; and the water flux over the simulated fuel array top are $0.589,0.701,0.614$ and 0.689 $\ell / \mathrm{s} / \mathrm{m}^{2}$, for Sprinklers CPK, ESFR-1, P1 and P3, respectively. Sprinkler CPK provided a thrust force and a water flux considerably lower than those provided by the other three sprinklers. With $7.77 \mathrm{~m}$ storage height $/ 4.42 \mathrm{~m}$ ceiling clearance and ignition directly under a sprinkler, Sprinkler CPK did not achieve fire suppression; the other sprinklers did. Furthermore, as observed in Tests 3 through 6, the larger the thrust force and the water flux of the ESFR sprinkler spray, the quicker the fire was suppressed. Therefore, for a fire located directly under a sprinkler with large ceiling clearance, the critical spray characteristics for achieving fire suppression are considered to be center-core thrust force and water flux over the fuel array top. In order to ensure the ESFR sprinkler's fire suppression capability for the case with ignition directly under a sprinkler, we have selected the minimum requirements of the center-core thrust force at $2.13 \mathrm{~m}$ beneath the ceiling and the water flux over a $2.15 \mathrm{~m} \mathrm{x}$ $2.15 \mathrm{~m}$ area at $4.42 \mathrm{~m}$ beneath the ceiling to be $101.3 \mathrm{~N} / \mathrm{m}^{2}$ and $0.614 / \mathrm{s} / \mathrm{m}^{2}$, respectively, for the FMRC's Sprinkler Approval Standard.

In Test 7, ignition and the main fuel array were centered below two sprinklers, and the ceiling clearance was only $1.37 \mathrm{~m}$. Fire gases rose only through the center flue of the main fuel array before sprinkler actuation. Most of the sprinkler water projected toward the main array reached the array without passing through the plume, and the water flux over the top surface of the fuel array measured under no-fire condition is expected to be close to that in the actual fire test. The water distribution in a $2.15 \mathrm{~m} \times 2.15 \mathrm{~m}$ area at $1.37 \mathrm{~m}$ below the ceiling, centered below two ESFR sprinklers (ESFR-1) was measured, and the average water flux over this area was $0.667 \mathrm{l} / \mathrm{s} / \mathrm{m}^{2}$. In Test 7, two sprinklers operated and suppressed the fire. Therefore, the water flux of $0.667 \mathrm{l} / \mathrm{s} / \mathrm{m}^{2}$ over the fuel array top at $1.37 \mathrm{~m}$ beneath the ceiling is considered to be sufficient for achieving fire suppression; and this value is adopted in the FMRC Approval Standard to ensure sufficient overlapping of two adjacent sprays at a small ceiling clearance of $1.37 \mathrm{~m}$.

\section{CONCLUSIONS}

ESFR sprinklers with proper spray characteristics can achieve fire suppression for rack storages of the FM Standard Plastic Commodity up to $10.8 \mathrm{~m}$ high in a $12.2 \mathrm{~m}$ high warehouse. A sprinkler spray can be characterized by its drop size distribution, center core thrust force, and water distribution under no fire condition. For ESFR sprinkler protection, the effect of drop size distribution has been demonstrated to be unimportant through the fire tests. For the case with ignition directly under a sprinkler, the spray center-core thrust force and the water flux under no-fire condition over the top surface of a two-pallet-load by two pallet-load fuel array directly underneath the sprinkler have been shown to be critical for achieving fire suppression. A minimum center-core thrust force of $101.3 \mathrm{~N} / \mathrm{m}^{2}$ measured at 1.77 beneath the sprinkler deflector, and a minimum water flux of $0.614 \mathrm{l} / \mathrm{s} / \mathrm{m}^{2}$ measured over a $2.15 \mathrm{~m} \times 2.15 \mathrm{~m}$ area $4.42 \mathrm{~m}$ beneath the ceiling directly under the sprinkler have been found to be necessary for achieving fire suppression. For the case with ignition centered below two sprinklers and with $10.8 \mathrm{~m}$ storage height / $1.77 \mathrm{~m}$ ceiling clearance, only the water flux under no-fire condition over the fuel array top was shown to be critical. A measured water flux of $0.667 \mathrm{l} / \mathrm{s} / \mathrm{m}^{2}$ over a $2.15 \mathrm{~m} \mathrm{x} 2.15 \mathrm{~m}$ area, centered below the two sprinklers, $1.77 \mathrm{~m}$ beneath 
the ceiling, was found to be sufficient for achieving fire suppression. These requirements for center-core thrust force and water flux under no-fire condition have been adopted in the FMRC Approval Standard for ESFR sprinklers.

\section{REFERENCES}

1. Yao, C., "The Development of the ESFR Sprinkler System," Fire Safety Journal, 14, p. $65,1988$.

2. NFPA 231 Standard for General Storage, 1985 Edition, National Fire Protection Association, Quincy, MA, 1995.

3. Factory Mutual Loss Prevention Data 2-2: Early Suppression-Fast Response Sprinklers, Factory Mutual Engineering Corporation, Norwood, MA, 1990.

4. Lee, J.L., "Early Suppression Fast Response (ESFR) Program, Phase I: Determination of Required Delivered Density (RDD) in Rack Storage Fires of Plastic Commodity," FMRC Technical Report, J.I. 0J0J5.RA, Factory Mutual Research Corporation, Norwood, MA, 1984.

5. Yu, H-Z., Lee, J.L., and Kung, H-C., "Suppression of Rack-Storage Fires by Water," The Proceedings of the Fourth International Symposium of Fire Safety Science, p. 901, 1994.

6. Kung, H-C., Yu, H-Z., Brown, W.R. and Vincent, B.G., "Four-Tier Array Rack Storage Fire Tests with Fast-Response Prototype Sprinklers," The Proceedings of the Second International Symposium of Fire Safety Science, p. 633, 1988.

7. Kung, H-C., Yu, H-Z., Brown, W.R. and Vincent, B.G., "Early Suppression-Fast Response (ESFR) Program, Phase III: Rack Storage Fire Tests with Fast-Response Prototype Sprinklers," FMRC Technical Report J.I. 0N1J5.RA, Factory Mutual Research Corporation, Norwood, MA, 1989.

8. Chicarello, P.J., Troup, J.M.A., and Dean, R.K., "Large-Scale Fire Test Evaluation of Early Suppression-Fast Response (ESFR) Automatic Sprinklers," FMRC Technical Report J.I. 0M2R5.RR, Factory Mutual Research Corporation, Norwood, MA, 1986.

9. Kung, H-C. and Spaulding, R.D., "Intermediate-Scale Rack Storage Fire Tests," FMRC Progress Report, J.I. 0F0F3.RU/0J0E1.RA, Factory Mutual Research Corporation, Norwood, MA, 1983.

10. Nam, S., "Numerical Simulation of Actual Delivered Density of Selected ESFR Sprinklers, Part II: Simulation and Validation," FMRC Technical Report J.I. OR0J1.RA/0R0J2.RA(2), Factory Mutual Research Corporation, Norwood, MA, 1995. 
11. Yu, H-Z. and Symonds, A.P., "Sprinkler Drop-Size Measurements, Part I: An Investigation of the FMRC PMS Drop-Size Measuring System," FMRC Technical Report J.I. 0G1E7.RA, Factory Mutual Research Corporation, Norwood, MA, 1982.

12. Chan, T-S., "Measurements of Spray Characteristics of Selected ESFR Sprinklers," Journal of Fire Protection Engineering, 6 (2), p. 11, 1994.

13. Dombrowski, N. and Wolfsohn, D.L., "The Atomization of Water by Swirl Spray Pressure Nozzles," Trans. Instn. Chem. Engrs., Vol. 50, p. 259, 1992.

14. Dundas, P.H., "The Scaling of Sprinkler Discharge - Prediction of Drop Size," FMRC Technical Report RC73-T-40, Factory Mutual Research Corporation, Norwood, MA, 1973. 